\title{
Evaluation of Nitrogen Utilization and the Effects of Monensin in Dairy Cows Fed Brown Midrib Corn Silage ${ }^{1}$
}

\author{
A. M. Gehman, P. J. Kononoff, ${ }^{2}$ C. R. Mullins, and B. N. Janicek \\ Department of Animal Science, University of Nebraska, Lincoln 68583-0908
}

\section{ABSTRACT}

Twenty midlactation Holstein cows (4 ruminally fistulated) averaging $101 \pm 34 \mathrm{~d}$ in milk and weighing 674 $\pm 77 \mathrm{~kg}$ were used to compare rations with brown midrib corn silage ( $\mathrm{bm} 3$ ) to rations with dual-purpose control silage (DP) on $\mathrm{N}$ utilization and milk production. The effect of monensin in these rations was also examined. Animals were assigned to one of five $4 \times 4$ Latin squares with treatments arranged in a $2 \times 2$ factorial. Cows were fed 1 of 4 treatments during each of the four 28d periods. Treatments were 1) $0 \mathrm{mg} / \mathrm{d}$ monensin and bm 3 corn silage, 2) $0 \mathrm{mg} / \mathrm{d}$ monensin and DP corn silage, 3) $300 \mathrm{mg} / \mathrm{d}$ monensin and bm3 corn silage, and 4) 300 $\mathrm{mg} / \mathrm{d}$ monensin and DP corn silage. In vitro 30 -h neutral detergent fiber (NDF) digestibility was greater for $b m 3$ corn silage ( 61.0 vs. $49.1 \pm 0.62)$. Dry matter intake (DMI) tended to be greater for cows consuming bm3 corn silage (21.3 vs. $20.2 \mathrm{~kg} / \mathrm{d})$. Neither hybrid nor monensin affected milk production, fat, or protein (37.7 $\mathrm{kg}, 3.60 \%$, or $3.04 \%$ ). Monensin tended to increase rumen $\mathrm{pH}(5.89$ vs. $5.79 \pm 0.07)$ compared with the control treatment. In addition, $b m 3$ corn silage resulted in a significant decrease in rumen $\mathrm{pH}$ (5.72 vs. $5.98 \pm 0.07)$. Supplementing monensin had no effect on molar proportions of acetate, propionate, or butyrate. In contrast, an increase was observed in branched-chain volatile fatty acids. No treatment interactions were observed for rumen $\mathrm{pH}$ or molar proportion of propionate but monensin decreased the molar proportion of acetate and increased the molar proportion of butyrate when cattle consumed bm 3 silage. Dry matter, $\mathrm{N}$, and acid detergent fiber digestibility were lower for the $b m 3$ ration, whereas NDF digestibility was not different between treatments. There was no effect of hybrid on

Received February 8, 2007.

Accepted September 14, 2007.

${ }^{1} \mathrm{~A}$ contribution of the University of Nebraska Agricultural Research Division, supported by Dow AgroSciences, LLC (Indianapolis, IN) and funds provided through the Hatch Act. Mention of a trade name, proprietary products, or company name is for presentation clarity and does not imply endorsement by the authors of the University of Nebraska.

${ }^{2}$ Corresponding author: pkononoff2@unl.edu microbial protein synthesis $(1,140 \mathrm{~g} / \mathrm{d})$ as estimated by urinary concentration of purine derivatives. Cows consuming bm3 excreted more fecal $\mathrm{N}$ than cows consuming DP (38.2 vs. $34.4 \% \mathrm{~N}$ intake); however, based on spot sampling, estimated urinary and manure $\mathrm{N}$ were not different between treatments $(35.8$ and $71.9 \% \mathrm{~N}$ intake). Monensin had no effect on DMI, digestibility of any nutrients, or $\mathrm{N}$ metabolism, and there were no hybrid by monensin interactions. Rations including bm3 corn silage tended to increase DMI but did not affect production. The reduction in the digestibility of some nutrients when cows consumed bm3 may have been caused by increased DMI and possible increased digestion in the lower gut. This increase in DMI appeared to also have negatively affected $\mathrm{N}$ digestibility but not NDF digestibility. This resulted in a greater amount of $\mathrm{N}$ excreted in feces but did not affect total mass of manure $\mathrm{N}$.

Key words: monensin, nitrogen, corn silage, lignin

\section{INTRODUCTION}

Lignin is a complex of phenylpropanoid polymers and is a component of plant cell walls. Lignin cross-links with carbohydrates such as cellulose and hemicellulose in the cell wall and acts to provide mechanical strength to the plants stem while also providing a protective barrier against pests and pathogens (Vignols et al., 1995; Marita et al., 2003). The brown midrib 3 mutation (bm3) of corn (Zea mays L.) reduces the content of lignin and increase the extent of fiber digestion in ruminants (Oba and Allen, 2000b). As a consequence of improved fiber digestibility, the amount of available energy may be greater for cows consuming bm3 corn silage compared with those consuming conventional hybrids. However, the extent of energy utilization may be limited because cows fed $\mathrm{bm} 3$ silage usually consume more feed (Oba and Allen, 1999; Tine et al., 2001), thus reducing total diet digestibility (Weiss and Wyatt, 2006). Several studies have reported that cows consumed more feed when fed bm3 corn silage compared with an isogenic control (Oba and Allen, 1999; Greenfield et al., 2001; Tine et al., 2001). Recently, Weiss and Wyatt (2006) demonstrated that cows consuming bm3 corn 
silage excreted less manure $\mathrm{N}$ compared with a dualpurpose control hybrid. These authors suggested that improved fermentability of $b m 3$ corn silage may have increased rumen microbial protein synthesis and $\mathrm{N}$ utilization.

When fed to lactating dairy cows, the ionophore monensin has been demonstrated to affect $\mathrm{N}$ utilization and may reduce the rate of ammonia production by some rumen bacteria (Chen and Russell, 1989) by affecting protein degradation (Ali Haimoud et al., 1995; Ruiz et al., 2001). This, in turn, results in an increase in the amount of feed protein reaching the lower gut (Ali Haimoud et al., 1995). With similar effects on rumen ammonia concentrations, several studies have observed that feeding monensin increases apparent $\mathrm{N}$ digestibility (Plaizier et al., 2000; Ruiz et al., 2001). Ruiz et al. (2001) speculated that this response was due to an increase in the supply of feed protein reaching the small intestine. Although digestibility of microbial $\mathrm{N}$ is high (Van Soest, 1994), when protein from feed is more digestible than that of microbial origin, amino acid uptake by the small intestine may increase when monensin is fed.

The effects of feeding $b m 3$ corn silage and monensin on $\mathrm{N}$ utilization, fecal $\mathrm{N}$ excretion, and milk production have not been evaluated together. An experiment doing so may provide new knowledge concerning the effects of feeding $b m 3$ corn silage and monensin. Because feeding bm3 corn silage may reduce $\mathrm{N}$ excretion (Weiss and Wyatt, 2006) and monensin may reduce fecal $\mathrm{N}$ output (Ruiz et al., 2001), an experiment evaluating both of these factors may demonstrate if these effects would be additive in total reducing $\mathrm{N}$ excretion. The objectives of this study were to use a factorial arrangement of treatments and to simultaneously evaluate the effects of feeding bm3 corn silage and monensin on $\mathrm{N}$ utilization and milk production and composition. We hypothesize that when fed to dairy cows, $b m 3$ corn silage and monensin will act independently to improve $\mathrm{N}$ utilization and that these effects will be additive.

\section{MATERIALS AND METHODS}

\section{Silage, Experimental Treatments, and Design}

Two corn hybrids, a dual-purpose (DP; Mycogen 7511 FQ, Dow AgroSciences LLC, Indianapolis, IN) and a bm3 (Mycogen F2F797, Dow AgroSciences LLC) were planted during spring 2004 at the University of Nebraska Agricultural Research and Development Center located near Mead, Nebraska. Corn silage was harvested using a self-propelled forage harvester (model 6750, John Deere, Moline, IL). Approximately 50 t of each hybrid were placed in bag silos (Ag/Bag International Ltd., Warrenton, OR) and ensiled for $210 \mathrm{~d}$. Table
Table 1. Chemical composition of the dual-purpose (control, DP) and brown midrib $(\mathrm{bm} 3)$ corn silages and grass hay (DM basis $)^{1}$

\begin{tabular}{|c|c|c|c|c|c|c|}
\hline \multirow[b]{2}{*}{ Item } & \multicolumn{2}{|c|}{ DP } & \multicolumn{2}{|c|}{ bm3 } & \multicolumn{2}{|c|}{ Grass hay } \\
\hline & Mean & SD & Mean & SD & Mean & SD \\
\hline Chemical, \% DM & 32.6 & 1.75 & 30.0 & 0.84 & 91.9 & 1.08 \\
\hline $\mathrm{CP}, \%$ & 9.2 & 0.73 & 9.2 & 0.89 & 10.6 & 3.0 \\
\hline Soluble CP, \% CP & 55.3 & 2.63 & 52.0 & 1.15 & 30.8 & 3.8 \\
\hline $\mathrm{NDF}, \%$ & 42.3 & 5.13 & 40.2 & 2.97 & 66.7 & 1.45 \\
\hline $\mathrm{ADF}, \%$ & 25.95 & 1.91 & 23.2 & 0.77 & 42.5 & 2.65 \\
\hline Lignin, \% & 3.5 & 0.19 & 2.4 & 0.30 & 5.93 & 0.81 \\
\hline Starch, \% & 30.5 & 2.20 & 29.5 & 1.97 & - & - \\
\hline Ether extract, \% & 3.0 & 0.23 & 3.0 & 0.53 & 2.4 & 0.41 \\
\hline $\mathrm{NFC}^{2} \%$ & 40.3 & 4.09 & 41.9 & 2.51 & 15.8 & 3.08 \\
\hline Ash, \% & 5.69 & 0.16 & 5.96 & 1.19 & 8.86 & 1.35 \\
\hline $\mathrm{Ca}, \%$ & 0.27 & 0.01 & 0.3 & 0.02 & 0.36 & 0.07 \\
\hline $\mathrm{Mg}, \%$ & 0.17 & 0.01 & 0.21 & 0.01 & 0.13 & 0.02 \\
\hline $\mathrm{P}, \%$ & 0.26 & 0.01 & 0.25 & 0.01 & 0.25 & 0.05 \\
\hline $\mathrm{K}, \%$ & 1.03 & 0.05 & 1.04 & 0.07 & 2.10 & 0.53 \\
\hline \multicolumn{7}{|l|}{ Particle size } \\
\hline$>19.0 \mathrm{~mm}, \%$ & 3.72 & 0.85 & 3.22 & 0.63 & - & - \\
\hline $19.0-8.0 \mathrm{~mm}, \%$ & 60.4 & 4.11 & 71.3 & 0.40 & - & - \\
\hline $8.0-1.18 \mathrm{~mm}, \%$ & 34.6 & 5.35 & 25.1 & 4.28 & - & - \\
\hline$<1.18 \mathrm{~mm}, \%$ & 1.50 & 1.68 & 0.43 & 0.46 & - & - \\
\hline
\end{tabular}

${ }^{1} \mathrm{n}=4$, samples were collected during the last week of each period. ${ }^{2} \mathrm{NFC}$ calculated by difference $100-(\% \mathrm{NDF}+\% \mathrm{CP}+\%$ fat $+\%$ ash).

1 outlines the nutrient composition and particle size measurements of the corn silage used in the experimental diets. Twenty lactating multiparous Holstein cows averaging $101 \pm 34 \mathrm{~d}$ (mean $\pm \mathrm{SD}$ ) DIM and weighing $674 \pm 77 \mathrm{~kg}$ were randomly assigned to one of five $4 \times$ 4 Latin squares (using a $2 \times 2$ factorial arrangement of treatments). Cannulated cows were assigned to 1 Latin square and randomly assigned to experimental treatments. Remaining cows were blocked by DIM and then randomly assigned to treatment sequences in 4 replicated $4 \times 4$ Latin squares. During each of the 28 d periods, cows were offered 1 of 4 TMR that differed by corn silage hybrid (DP or bm3) and monensin inclusion rate $(0$ or $300 \mathrm{mg} / \mathrm{d})$. Treatments were 1$) 0 \mathrm{mg} / \mathrm{d}$ monensin and $b m 3$ corn silage, 2) $0 \mathrm{mg} / \mathrm{d}$ monensin and DP corn silage, 3) $300 \mathrm{mg} / \mathrm{d}$ monensin and $\mathrm{bm} 3$ corn silage, and 4) $300 \mathrm{mg} / \mathrm{d}$ monensin and DP corn silage. Monensin was top-dressed and hand-mixed into the TMR contained in the bunk. One square (4 cows) included ruminally cannulated cows, and was used for all rumen measurements, whereas all squares were used for production and intake data. Cows were housed in individual stalls and milked at 0730 and $1930 \mathrm{~h}$. Cows were fed at $1000 \mathrm{~h}$ for ad libitum consumption to allow for approximately $5 \%$ refusals. The experimental cows were cared for according to the guidelines stipulated by the University of Nebraska Animal Care Committee (IACUC \#05-11-07OD).

In formulating experimental diets, the strategy was to develop diets similar in concentrations of NDF and 
NFC. Preliminary forage analysis of green chop material indicated that $\mathrm{bm} 3$ corn silage had a lower concentration of NDF ( 40.8 vs. $45.0 \% \mathrm{DM}$ ) but greater concentration of starch (29.7 vs. $26.2 \% \mathrm{DM})$ than the DP hybrid (Table 1). As a consequence, diets containing bm 3 corn silage were formulated to contain 5\% less ground corn and 5\% more corn silage. Table 1 lists the chemical composition of forages from samples collected throughout the experiment $(n=4)$. Assuming a DMI of 22.7 $\mathrm{kg} / \mathrm{d}$, the NRC (2001) model predicted $\mathrm{NE}_{\mathrm{L}}$ allowable milk of $38.7 \mathrm{~kg} / \mathrm{d}$ and MP allowable milk of $38.7 \mathrm{~kg} / \mathrm{d}$ for cows consuming this diet. In comparison and at the same level of intake, the NRC (2001) model predicted that $\mathrm{NE}_{\mathrm{L}}$ allowable milk was $38.5 \mathrm{~kg} / \mathrm{d}$ and $\mathrm{MP}$ allowable milk was $38.6 \mathrm{~kg} / \mathrm{d}$ for cows consuming the DP diet.

\section{Experimental Measures}

Particle Size, BW, BCS, and Milk Composition. The Penn State Particle Separator (PSPS) was used to measure particle size for both forages and TMR as described by Kononoff et al. (2003a). Body weight and BCS (1 to 5 scale) were measured on d 27 and 28 of each period. Body condition score was measured by a single trained individual, and the scoring method used was similar to that of Wildman et al. (1982), but reported to the quarter point. Milk production was measured daily and milk samples were collected during the a.m. and p.m. milkings of $d 26,27$, and 28 and preserved using 2-bromo-2-nitropropane-1,3 diol. During the last week of each period, daily DMI and milk yield were averaged. Milk samples were analyzed for fat and true protein (AOAC, 2000) using a B2000 Infrared Analyzer (Bentley Instruments, Chaska, MN) by Heart of America DHIA (Manhattan, KS).

Ruminal Sampling. Commencing at $0800 \mathrm{~h}$ on $\mathrm{d}$ 27 of each period ruminal contents were collected from the dorsal, ventral, and caudal area in the rumen at 0800, 0930, 1130, 1330, 1630, 1930, 2230, 0200, 0530, and $0730 \mathrm{~h}$. Collected digesta were mixed and filtered through 4 layers of cheesecloth. Rumen liquid $\mathrm{pH}$ was immediately determined by using a hand-held $\mathrm{pH}$ electrode (model M90, Corning Inc., Corning, NY). Approximately $15 \mathrm{~mL}$ of filtered liquid was then placed into bottles containing $3 \mathrm{~mL}$ of $25 \%$ metaphosphoric acid and $3 \mathrm{~mL}$ of $0.6 \%$ 2-ethyl butyric acid (internal standard) and stored at $-20^{\circ} \mathrm{C}$. Samples were later centrifuged 3 times at $4,000 \times g$ for $30 \mathrm{~min}$ at $4^{\circ} \mathrm{C}$ to obtain a clear supernatant that was analyzed for ammonia using a phenol-hypochlorite assay (Lykos et al., 1997) and VFA concentration using gas chromatography (Yang and Varga, 1989).

Apparent Digestibility and Nitrogen Excretion. Nutrient digestibility was estimated using the marker technique with indigestible ADF (Huhtanen et al., 1994). The TMR and fecal samples were weighed $(0.35$ g) into $5-\times 10-\mathrm{cm}$ Dacron bags with $50-\mu \mathrm{m}$ pores (No. R510; Ankom Technology, Fairport, NY) and incubated in the rumen of a lactating cannulated cow fed a diet containing $60 \%$ forage and $40 \%$ concentrate for $12 \mathrm{~d}$ for indigestible $\mathrm{ADF}$ determination. Apparent digestibility of nutrients was estimated based on the concentration of indigestible ADF in the TMR and feces, and N excretion in feces was calculated from the obtained $\mathrm{N}$ digestibility and $\mathrm{N}$ intake.

Fecal and urine samples were collected on all cows at 0600 and $1800 \mathrm{~h}$ during the last $4 \mathrm{~d}$ of each period. Feces were sampled from the rectum and urine during urination with stimulation. Fecal samples were pooled to obtain a composite for individual cows in each period. Fecal samples were dried at $55^{\circ} \mathrm{C}$ in a forced air oven, ground ( $1 \mathrm{~mm}$ screen; Wiley mill, Arthur H. Thomas Co., Philadelphia, PA) and composited according to cow and period. Ground samples were analyzed for DM $\left(100^{\circ} \mathrm{C}\right.$ oven for $\left.24 \mathrm{~h}\right)$. Feed and fecal samples were analyzed for nitrogen (Leco FP-528, Leco Corp., St. Joseph, MI), ether extract (AOAC, 2000), and percentage ash (AOAC, 2000). Both NDF and ADF were analyzed using an Ankom Fiber Analyzer (Ankom Technology). Heat stable $\alpha$-amylase (number A3306; Sigma Chemical Co., St. Louis, MO) was included in the NDF procedure $(100 \mu \mathrm{L}$ per $0.50 \mathrm{~g}$ of sample). Whole-diet total digestible nutrient concentration was then determined (Weiss et al., 1992) and, based on these values, production levels of digestible energy, $\mathrm{ME}$, and $\mathrm{NE}_{\mathrm{L}}$ were calculated as outlined by NRC (2001). Samples of urine were acidified to $\mathrm{pH}<4$ using $4 \mathrm{MHCl}$ and frozen $\left(-20^{\circ} \mathrm{C}\right)$. Urine samples were later thawed and composited for each cow during each period. Urinary creatinine has been validated as a marker to estimate urine volume (Valadares et al., 1999; Leonardi et al., 2003). The ratio of urinary purine derivatives (PD) namely, allantoin, uric acid, xanthine, and hypoxanthine in urine are widely used to estimate the microbial protein flow (MCP) to the duodenum (Gonda, 1995; Shingfield and Offer, 1998). Purine derivatives and creatinine were analyzed by HPLC (Waters Corp., Milford, MA) according to the procedures of Shingfield and Offer (1998). Urine samples were analyzed for N. Urinary creatinine was used as a marker to estimate urine volume. In calculating urine volume we assumed that creatinine output averages $28 \mathrm{mg} / \mathrm{kg}$ of BW as estimated by Whittet (2004). Previous investigators have reported similar daily creatinine output ranging from 25 to $30 \mathrm{mg} / \mathrm{kg}$ of BW (McCarthy et al., 1983; Jones et al., 1990). The ratio of urinary $\mathrm{PD}$ allantoin and uric acid to creatinine (PD:C) was used to estimate relative differences in microbial protein production (Shingfield and Offer, 1998). 
Based on estimates of urinary excretion of $\mathrm{PD}$, microbial protein supply was estimated by Chen and Gomes (1992).

In Vitro Estimates of NDF and Dry Matter Digestibility. Two ruminally cannulated British-breed crossbred steers that were housed in individual stalls were used to collect rumen fluid for determination of in vitro rumen $\mathrm{NDF}$ and DM digestibility of both corn hybrids. The basal diet consisted of $70 \%$ grass hay and $30 \%$ concentrate fed twice daily for a total intake of $1.5 \%$ of BW. In vitro disappearance of the forage samples (1mm grind) was determined using the Tilley and Terry (1963) method but modified by the addition of $1 \mathrm{~g} / \mathrm{L}$ of urea to the McDougall's buffer (Weiss, 1994). Incubation time points for determination of NDF digestibility was $30 \mathrm{~h}$ and for DM were as follows: $2,4,8,16,24$, 36, 48, and $96 \mathrm{~h}$. Estimates for kinetics of rumen in vitro DM digestibility were determined using the $\mathrm{Ne}-$ way-Excel computer program (Chen, 1997) according to the following model:

$$
y=a+b\left(1-e^{-c(t-L)}\right)
$$

where $\mathrm{a}=$ soluble fraction, $\% ; \mathrm{b}=$ slowly digestible fraction, \%; $\mathrm{c}=$ fractional rate of $\mathrm{DM}$ disappearance, $\% / \mathrm{h} ; \mathrm{L}=\mathrm{lag}$ time, $\mathrm{h}$; and $\mathrm{t}=$ time of incubation, $\mathrm{h}$.

Effective rumen degradability was estimated by rearranging the terms as follows:

$$
\mathrm{y}=\mathrm{a}+\mathrm{b}[\mathrm{c} /(\mathrm{c}+\mathrm{k})] \mathrm{e}^{(-\mathrm{k} \times \mathrm{L}) / 100)}
$$

where $\mathrm{k}=$ rate constant for fractional rate of passage was assumed $(0.05$ and $0.08 \% / \mathrm{h})$.

Statistical Analyses. Performance data were analyzed as a replicated $4 \times 4$ Latin square with model effects for square, period within square, and treatment as fixed effects, as well as cow within square as a random effect. Sum of squares for all treatments were then partitioned into single degree of freedom contrasts for corn silage hybrid and inclusion on monensin and interaction as planned a priori. The first-order autoregressive covariance structure [AR(1)] and the MIXED procedure of SAS (version 9.1, SAS Institute Inc., Cary, NC) were used to analyze all data. Repeated measurements of rumen ammonia, $\mathrm{pH}$, and VFA concentration were analyzed by including a REPEATED model statement, as well as a term for time and interaction for treatment by time. Square by treatment interaction was tested but was not significant, and therefore it was dropped from the model. Significance for all models was declared at $P \leq 0.05$, and trends are discussed at $P \leq 0.10$. All means presented are least squares means.
Table 2. In vitro 30-h NDF digestibility and DM digestibility of the dual-purpose (control, DP) and brown midrib $(\mathrm{bm} 3)$ corn silages

\begin{tabular}{lccc}
\hline & \multicolumn{2}{c}{ Hybrid } & \\
\cline { 2 - 3 } Item & DP & $b m 3$ & SEM \\
\hline 30-h in vitro NDF digestion, \% NDF & 49.1 & 61.0 & 0.62 \\
In vitro DM digestibility & & & \\
$\quad$ Fraction a (soluble fraction), \% of DM & 15.0 & 18.2 & 0.69 \\
Fraction b (slowly digestible fraction), & & & \\
$\quad$ \% of DM & 60.0 & 62.3 & 1.07 \\
$\quad$ Rate, \% of DM/h & 6.60 & 5.70 & 0.85 \\
$\quad$ Lag, h & 1.25 & 0.75 & 0.11 \\
Potentially degraded, \% of DM & 75.0 & 80.5 & 1.71 \\
Effective rumen degradability, \% of DM & & & \\
$\quad$ 0.05\% DM/h fractional rate of passage & 49.0 & 51.4 & 1.13 \\
0.08\% DM/h fractional rate of passage & 42.1 & 44.2 & 1.16 \\
\hline
\end{tabular}

\section{RESULTS AND DISCUSSION}

\section{Forage and Ration Chemical Composition and Particle Size}

Table 1 lists the chemical composition of the forages fed during the experiment. The CP content of the DP and $b m 3$ corn silages was similar $(9.2 \% \mathrm{DM})$ but DP had greater NDF $(42.3 \pm 5.1 \%)$ and lignin $(3.5 \pm 0.2$ $\%)$ content compared with $b m 3(\mathrm{NDF}=40.2 \pm 3.0 \%$; lignin $=2.4 \pm 0.30 \%$ ). The lower lignin content of $\mathrm{bm} 3$ was expected and was similar to that reproted previously (Oba and Allen, 2000a; Weiss and Wyatt, 2006). As expected, in vitro estimates of NDF digestibility following a 30 -h incubation (Table 2 ) were greater for $\mathrm{bm} 3$ corn silage compared with DP corn silage (61.0 vs. 49.1 $\pm 0.62 \%$ ), with this difference being similar to that of others (Ebling and Kung, 2004). In vitro estimates of DM digestibility are listed in Table 2 . The $b m 3$ silage had a greater soluble "a" fraction (18.2 vs. $15.0 \pm 0.69 \%$ $\mathrm{DM})$ and digestible "b" fraction (62.3 vs. $60.0 \pm 1.07 \%$ $\mathrm{DM})$, but the rate of $\mathrm{DM}$ digestion and lag were both slightly lower $(6.60$ vs. $5.70 \pm 0.85 \% / \mathrm{h}$ and 1.25 vs. 0.75 $\pm 0.11 \mathrm{~h}$ ).

Ingredients and chemical composition of experimental diets are listed in Table 3. Although differences in NDF and starch between hybrids were lower than preliminary green-chop results (Table 1), the diets still contained similar amounts of NDF (33.4 and 33.7\% DM for DP and $b m 3$, respectively) and starch (27.0 and $26.9 \% \mathrm{DM}$ for DP and $b m 3$, respectively). Diets were formulated similarly in $\mathrm{NE}_{\mathrm{L}}$ and $\mathrm{MP}$ according to the NRC (2001). Forage and ration particle size estimates according to the PSPS are listed in Tables 1 and 4 . Particle size estimates of both silage hybrids and experimental diets are similar to those recommended by Heinrichs and Kononoff (2002). Although particle size estimates of forage were similar, diets containing $b m 3$ corn silage were coarser and contained $51.0 \%$ material $>8$ 
Table 3. Ingredient and chemical composition of total mixed diets fed during lactation

\begin{tabular}{|c|c|c|}
\hline & \multicolumn{2}{|c|}{$\operatorname{Diet}^{1}$} \\
\hline & $\mathrm{DP}$ & $b m 3$ \\
\hline \multicolumn{3}{|l|}{ Diet ingredients } \\
\hline DP corn silage & 49.2 & - \\
\hline bm3 corn silage & - & 54.3 \\
\hline Grass hay & 4.0 & 4.0 \\
\hline Wet corn gluten feed & 4.0 & 4.0 \\
\hline Whole cottonseed & 5.6 & 5.6 \\
\hline Ground corn & 17.5 & 12.3 \\
\hline Limestone & 1.6 & 1.6 \\
\hline Soybean hulls & 4.0 & 3.6 \\
\hline Soypass $^{2}$ & 4.0 & 4.0 \\
\hline Magnesium oxide & 0.16 & 0.16 \\
\hline Megalac & 0.66 & 0.66 \\
\hline Soybean meal, $48 \%$ & 7.6 & 7.9 \\
\hline Tallow & 0.50 & 0.50 \\
\hline Sodium bicarbonate & 0.50 & 0.50 \\
\hline Salt & 0.20 & 0.20 \\
\hline Sel-Plex $1000^{3}$ & 0.02 & 0.02 \\
\hline Vitamin premix ${ }^{4}$ & 0.10 & 0.10 \\
\hline Mineral premix ${ }^{5}$ & 0.04 & 0.04 \\
\hline Urea & 0.30 & 0.40 \\
\hline \multicolumn{3}{|l|}{ Chemical composition } \\
\hline $\mathrm{CP}$ & 16.3 & 16.7 \\
\hline RUP ${ }^{6} \%$ of DM & 6.2 & 6.3 \\
\hline Soluble CP & 31.1 & 32.0 \\
\hline Starch & 27.0 & 26.9 \\
\hline NDF & 33.4 & 33.7 \\
\hline $\mathrm{ADF}$ & 20.5 & 20.0 \\
\hline Lignin & 1.77 & 1.51 \\
\hline $\mathrm{NE}_{\mathrm{L}}{ }^{6} \mathrm{Mcal} / \mathrm{kg}$ & 1.62 & 1.63 \\
\hline Ether extract & 5.1 & 5.2 \\
\hline $\mathrm{NFC}^{7}$ & 39.6 & 38.4 \\
\hline Ash & 6.46 & 6.51 \\
\hline $\mathrm{Ca}$ & 0.85 & 0.86 \\
\hline $\mathrm{Mg}$ & 0.33 & 0.34 \\
\hline $\mathrm{P}$ & 0.35 & 0.34 \\
\hline $\mathrm{K}$ & 1.17 & 1.19 \\
\hline
\end{tabular}

${ }^{1}$ Control ration containing dual-purpose (DP) control hybrid and treatment ration containing brown midrid hybrid (bm3).

${ }^{2}$ LignoTech (Overland Park, KS).

${ }^{3}$ Alltech, Inc. (Nicholasville, KY).

${ }^{4}$ Formulated to supply approximately 120,000 IU/d vitamin A; $24,000 \mathrm{IU} / \mathrm{d}$ of vitamin $\mathrm{D}$; and $800 \mathrm{IU} / \mathrm{d}$ vitamin $\mathrm{E}$ in total ration.

${ }^{5}$ Formulated to contain $1.0 \% \mathrm{Ca}, 0.50 \% \mathrm{P}, 0.36 \% \mathrm{Mg}, 1.3 \% \mathrm{~K}$.

${ }^{6}$ According to NRC (2001).

${ }^{7} \mathrm{NFC}$ calculated by difference $100-(\% \mathrm{NDF}+\% \mathrm{CP}+\%$ fat $+\%$ ash).

Table 4. Particle size of the control dual-purpose (DP) TMR and brown midrib (bm3) TMR

\begin{tabular}{|c|c|c|c|c|}
\hline \multirow[b]{2}{*}{ Particle size } & \multicolumn{2}{|c|}{ Treatment } & \multirow[b]{2}{*}{ SEM $^{1}$} & \multirow[b]{2}{*}{$P$-value } \\
\hline & DP & bm3 & & \\
\hline \multicolumn{5}{|c|}{ - TMR, \% retained - } \\
\hline$>19.0 \mathrm{~mm}$ & 2.43 & 2.80 & 0.44 & 0.60 \\
\hline $19.0-8.0 \mathrm{~mm}$ & 37.4 & 48.2 & 1.26 & $<0.01$ \\
\hline $8.0-1.18 \mathrm{~mm}$ & 45.6 & 40.7 & 0.70 & 0.11 \\
\hline$<1.18 \mathrm{~mm}$ & 14.6 & 9.37 & 0.44 & $<0.01$ \\
\hline
\end{tabular}

${ }^{1}$ Highest standard error of treatment means is shown. mm compared with $39.8 \%$ of DP corn silage (Table 5). This effect was likely due to the greater proportion of corn silage in $b m 3$ diets.

\section{Feed Intake and Feed Refusal Particle Size}

Intake tended to be greater ( 21.3 vs. $20.2 \pm 0.63 \mathrm{~kg} /$ d) for cows consuming $\mathrm{bm} 3$ corn silage but was not affected by monensin (Table 6 ). The observed response of intake in cows consuming $b m 3$ was expected and consistent with other studies (Oba and Allen, 2000a; Greenfield et al., 2001; Qiu et al., 2003; Ebling and Kung, 2004) but this response has not been observed in all studies (Weiss and Wyatt, 2006). In most published studies evaluating bm3 corn silage, $b m 3$ is compared with an isogenic control and diets are formulated to contain equal amounts of corn silage. In comparison, the current study substituted a portion of the corn silage with corn grain while maintaining the NDF and energy content of the diet. Results of this study support the suggestion of Oba and Allen (1999) that cows may consume more $b m 3$ corn silage because the NDF fraction is more readily hydrolyzed and allows for more capacity in the rumen, which results in greater feed intakes.

Evaluation of feed refusal particle size is useful because large differences may reflect selective consumption or sorting activity (Leonardi et al., 2005) that may affect both the physical characteristics and chemical composition of consumed feed and as a result, also affect ruminal fermentation (Kononoff et al., 2003b). Thus, in an effort to evaluate feeding behavior, the particle size of feed offered and refused was estimated by the PSPS and is listed in Table 5. The amount of material $>19.0$ $\mathrm{mm}$ was greater in refusals compared with the TMR (Table 4), but this was not affected by dietary treatment, averaging $12.4 \pm 2.54 \%$. Again, consistent with particle size estimates of the TMR, refusals containing bm3 corn silage had a greater proportion of particles between 8.0 and $19.0 \mathrm{~mm}(54.1$ vs. $47.9 \pm 2.54 \%)$ and tended to have less particles $<1.18-\mathrm{mm}$ (4.1 vs. $6.1 \pm$ $1.13 \%)$. Results of the current experiment are similar to those of Kononoff et al. (2003b), in which particles $>19.0 \mathrm{~mm}$ were more likely to be refused by dairy cattle. Differences observed in this experiment were small and likely are not reflective of intensive feed-sorting activity.

\section{Rumen pH, VFA, and Ammonia}

Effects of monensin and corn silage hybrid on rumen $\mathrm{pH}$, total VFA, ammonia concentrations, and molar proportion of individual VFA are presented in Table 7. Rumen $\mathrm{pH}$ tended to be greater in animals consuming 
Table 5. Effects of feeding monensin and different corn hybrids and interactions between these factors on particle size distribution of refusals of experimental diets

\begin{tabular}{|c|c|c|c|c|c|c|c|c|}
\hline \multirow[b]{2}{*}{ Particle size } & \multicolumn{4}{|c|}{ Treatment $^{1}$} & \multirow[b]{2}{*}{$\mathrm{SEM}^{2}$} & \multicolumn{3}{|c|}{ Contrast $^{3}(P$-value $)$} \\
\hline & C-bm3 & C-DP & M-bm3 & M-DP & & Monensin & Hybrid & I \\
\hline & \multicolumn{8}{|c|}{ $\%$ retained $\longrightarrow$} \\
\hline$>19.0 \mathrm{~mm}$ & 12.0 & 14.1 & 10.4 & 13.0 & 2.54 & 0.58 & 0.34 & 0.93 \\
\hline $19.0-8.0 \mathrm{~mm}$ & 57.0 & 48.6 & 51.2 & 47.1 & 2.42 & 0.11 & $<0.01$ & 0.35 \\
\hline $8.0-1.18 \mathrm{~mm}$ & 29.7 & 32.5 & 35.2 & 34.1 & 3.13 & 0.23 & 0.78 & 0.52 \\
\hline$<1.18 \mathrm{~mm}$ & 3.18 & 5.94 & 4.99 & 6.23 & 1.13 & 0.32 & 0.07 & 0.48 \\
\hline
\end{tabular}

monensin and is consistent with the observations of others (Green et al., 1999). Although ruminal lactate was not measured in the current study, elevations in rumen $\mathrm{pH}$ when animals are fed monensin are believed to occur because of the sensitivities of lactate-producing bacteria to this compound (Russell and Strobel, 1989). Monensin supplementation did not affect the molar proportion of acetate, propionate, and butyrate. In contrast, monensin was observed to have an increasing effect on branched-chain VFA, namely isobutyrate and isovalerate, but ruminal ammonia concentrations were not affected. The appearance of branched-chain VFA is believed to be a result of microbial deamination of the branched-chain AA valine and leucine (Allison, 1970; Yokoyama and Johnson, 1988).

Diets containing DP corn silage resulted in a greater mean $\mathrm{pH}$ compared with those containing bm3 corn silage (5.96 vs. $5.72 \pm 0.07$ ). Similar to the current study, reduced $\mathrm{pH}$ when feeding bm3 corn silage has been observed by others (Greenfield et al., 2001) and is believed to be a response to increasing the supply of fermentable substrate in the rumen (Weiss and Wyatt, 2006). When animals consumed diets containing DP corn silage, the proportion of ruminal propionate was greater ( 27.4 vs. $26.3 \pm 1.77 \%)$ and acetate:propionate ratio tended to be lower ( 2.09 vs. $2.18 \pm 0.22 \%$ ) and may have, in part, been a result of decreased intake. Feeding bm3 corn silage tended to decrease rumen ammonia and molar proportions of branched-chain VFA (isobutyrate and isovalerate). This effect has also been reported by Greenfield et al. (2001). These observations are likely due to greater fiber digestion and that cellulolytic bacteria such as Ruminococcus albus, Ruminococcus flavefaciens, and Fibrobacter succinogenes require these substrates for normal growth (Russell et al., 1992). Increases in fiber digestibility and resulting organic acids

Table 6. Effects of feeding monensin and different corn hybrids and interactions between these factors on milk yield and composition

\begin{tabular}{|c|c|c|c|c|c|c|c|c|}
\hline \multirow[b]{2}{*}{ Item } & \multicolumn{4}{|c|}{ Treatment $^{1}$} & \multirow[b]{2}{*}{$\mathrm{SEM}^{2}$} & \multicolumn{3}{|c|}{ Contrast $^{3}(P$-value $)$} \\
\hline & C-bm3 & C-DP & M-bm3 & M-DP & & Monensin & Hybrid & I \\
\hline DMI, kg/d & 21.1 & 20.1 & 21.5 & 20.2 & 0.63 & 0.67 & 0.08 & 0.86 \\
\hline Milk yield & 39.5 & 36.4 & 37.1 & 37.8 & 2.11 & 0.81 & 0.53 & 0.35 \\
\hline $\mathrm{FC}^{4}$ & 1.81 & 1.76 & 1.72 & 1.83 & 0.08 & 0.71 & 0.93 & 0.36 \\
\hline $3.5 \% \mathrm{FCM}$ & 40.3 & 36.6 & 37.1 & 38.0 & 2.09 & 0.66 & 0.50 & 0.26 \\
\hline Fat, \% & 3.65 & 3.58 & 3.55 & 3.63 & 0.16 & 0.87 & 0.99 & 0.64 \\
\hline Fat, kg/d & 1.43 & 1.29 & 1.30 & 1.34 & 0.08 & 0.61 & 0.54 & 0.28 \\
\hline Protein, \% & 3.03 & 3.05 & 3.07 & 3.02 & 0.06 & 0.92 & 0.82 & 0.54 \\
\hline Protein, kg/d & 1.18 & 1.09 & 1.13 & 1.12 & 0.06 & 0.80 & 0.41 & 0.41 \\
\hline Lactose & 4.74 & 4.68 & 4.73 & 4.67 & 0.07 & 0.82 & 0.34 & 0.99 \\
\hline MUN, mg/dL & 11.3 & 10.4 & 12.1 & 11.5 & 0.42 & 0.03 & 0.08 & 0.73 \\
\hline BW, kg & 703.5 & 699.6 & 712.0 & 701.2 & 16.8 & 0.76 & 0.65 & 0.83 \\
\hline $\mathrm{BCS}^{5}$ & 3.06 & 3.03 & 3.05 & 2.98 & 0.07 & 0.58 & 0.53 & 0.77 \\
\hline
\end{tabular}

${ }^{1} \mathrm{C}-\mathrm{bm} 3$ = no monensin, bm3 hybrid; C-DP = no monensin, dual-purpose control hybrid; M-bm3 = $300 \mathrm{mg} /$ $\mathrm{d}$ monensin, $b m 3$ hybrid; M-DP = $300 \mathrm{mg} / \mathrm{d}$ monensin, control dual-purpose hybrid.

${ }^{2}$ Highest standard error of treatment means is shown.

${ }^{3}$ Contrast for effects of feeding monensin and corn silage hybrid and monensin by hybrid interaction (I).

${ }^{4}$ Feed conversion $=$ milk yield/DMI.

${ }^{5} \mathrm{BCS}$ on 1 to 5 scale. 
Table 7. Effects of feeding monensin and different corn hybrids and interactions between these factors on ruminal concentration of volatile fatty acids and ammonia $\left(\mathrm{NH}_{3} \mathrm{~N}\right)$ on cows in early lactation

\begin{tabular}{|c|c|c|c|c|c|c|c|c|}
\hline \multirow[b]{2}{*}{ Item } & \multicolumn{4}{|c|}{ Treatment $^{1}$} & \multirow[b]{2}{*}{$\mathrm{SEM}^{2}$} & \multicolumn{3}{|c|}{ Contrast $^{3}$ ( $P$-value $)$} \\
\hline & C-bm3 & C-DP & M-bm3 & M-DP & & Monensin & Hybrid & I \\
\hline Rumen & 5.65 & 5.93 & 5.79 & 5.98 & 0.07 & 0.07 & $<0.01$ & 0.44 \\
\hline Total VFA $(\mathrm{m} M)$ & 133.7 & 130.4 & 139.8 & 135.1 & 5.20 & 0.16 & 0.29 & 0.85 \\
\hline VFA, mol/100 mol & & & & & & & & \\
\hline Acetate (A) & 55.4 & 55.2 & 55.0 & 56.7 & 1.30 & 0.18 & 0.07 & 0.03 \\
\hline Propionate (P) & 26.6 & 27.5 & 25.9 & 27.3 & 1.77 & 0.19 & $<0.01$ & 0.61 \\
\hline Isobutyrate & 1.20 & 1.25 & 1.24 & 1.46 & 0.08 & $<0.01$ & $<0.01$ & $<0.01$ \\
\hline Butyrate & 12.7 & 12.1 & 13.7 & 11.1 & 0.62 & 0.99 & $<0.01$ & $<0.01$ \\
\hline Isovalerate & 1.21 & 1.32 & 1.37 & 1.67 & 0.15 & $<0.01$ & $<0.01$ & 0.33 \\
\hline Valerate & 2.91 & 2.60 & 2.72 & 1.94 & 0.17 & $<0.01$ & $<0.01$ & 0.02 \\
\hline A:P & 2.16 & 2.05 & 2.19 & 2.13 & 0.22 & 0.18 & 0.07 & 0.54 \\
\hline $\mathrm{NH}_{3} \mathrm{~N}(\mathrm{mg} / \mathrm{dL})$ & 7.96 & 8.89 & 7.21 & 8.78 & 1.61 & 0.56 & 0.09 & 0.67 \\
\hline
\end{tabular}

likely also contributed to the observed decrease in rumen $\mathrm{pH}$, similar to findings of Yang and Yang (2002).

\section{Apparent Nutrient Digestibility}

Monensin did not affect apparent digestibility, nor did it interact with corn silage hybrid with respect to any nutrient (Table 8). Published studies reflect inconsistent effects of monensin on apparent nutrient digestibility when fed to lactating cows. Generally, when reported, monensin increases total tract fiber digestibility (Spears, 1990; Osborne et al., 2004). This is thought to be because the addition of monensin to ruminant diets frequently increases rumen $\mathrm{pH}$, thereby promoting fiber digestion in the rumen (Varga and Kolver, 1997). Although monensin tended to increase rumen $\mathrm{pH}$ in the current experiment, this likely had minimal effects on bacterial fermentation of fiber.

Dry matter, $\mathrm{N}$, and ADF digestibility were lower for diets containing $b m 3$ corn silage. This effect was likely due to the negative association between intake and digestibility (Van Soest, 1994). A reduction in CP digestibility from feeding $b m 3$ has been reported by others (Tine et al., 2001). These authors speculated that this effect may have been, in part, because of microbial $\mathrm{N}$ assimilation during hindgut fermentation. Differences

Table 8. Effects of feeding monensin and different corn hybrids and interactions between these factors on nutrient digestibility, $\mathrm{NE}_{\mathrm{L}}$, and energy balance

\begin{tabular}{|c|c|c|c|c|c|c|c|c|}
\hline \multirow[b]{2}{*}{ Item } & \multicolumn{4}{|c|}{ Treatment $^{1}$} & \multirow[b]{2}{*}{$\mathrm{SEM}^{2}$} & \multicolumn{3}{|c|}{ Contrast $^{3}$ ( $P$-value $)$} \\
\hline & C-bm3 & C-DP & M-bm3 & M-DP & & Monensin & Hybrid & I \\
\hline \multicolumn{9}{|l|}{ Digestibility } \\
\hline DM, \% & 59.7 & 62.2 & 59.5 & 62.9 & 1.15 & 0.84 & 0.02 & 0.76 \\
\hline $\mathrm{N}, \%$ & 61.9 & 64.9 & 61.8 & 66.3 & 1.15 & 0.55 & $<0.01$ & 0.51 \\
\hline $\mathrm{NDF}, \%$ & 40.0 & 39.8 & 41.3 & 40.7 & 2.42 & 0.66 & 0.85 & 0.94 \\
\hline $\mathrm{ADF}, \%$ & 31.3 & 39.1 & 31.7 & 42.1 & 3.66 & 0.64 & 0.01 & 0.71 \\
\hline Ether extract (EE), \% & 87.6 & 88.8 & 86.8 & 89.3 & 0.51 & 0.72 & $<0.01$ & 0.23 \\
\hline $\mathrm{OM}, \%$ & 63.3 & 65.2 & 63.6 & 65.9 & 1.17 & 0.64 & 0.07 & 0.85 \\
\hline $\mathrm{NFC}, 4 \%$ & 85.1 & 85.6 & 84.3 & 85.4 & 0.01 & 0.73 & 0.55 & 0.81 \\
\hline TDN, ${ }^{5} \%$ & 64.5 & 67.1 & 64.6 & 67.4 & 1.07 & 0.85 & 0.01 & 0.87 \\
\hline $\mathrm{NE}_{\mathrm{Lp}},{ }^{6} \mathrm{Mcal} / \mathrm{kg}$ & 1.54 & 1.62 & 1.54 & 1.63 & 0.034 & 0.84 & 0.01 & 0.85 \\
\hline Energy balance, Mcal/d & -6.34 & -3.55 & -4.11 & -4.10 & 1.52 & 0.57 & 0.35 & 0.35 \\
\hline
\end{tabular}

${ }^{1} \mathrm{C}-\mathrm{bm} 3$ = no monensin, bm3 hybrid; C-DP = no monensin, dual-purpose control hybrid; M-bm3 = $300 \mathrm{mg} /$ $\mathrm{d}$ monensin, $b m 3$ hybrid; M-DP $=300 \mathrm{mg} / \mathrm{d}$ monensin, control dual-purpose hybrid.

${ }^{2}$ Highest standard error of treatment means is shown.

${ }^{3}$ Contrast for effects of feeding monensin and corn silage hybrid and monensin by hybrid interaction (I).

${ }^{4} \mathrm{NFC}$ calculated by difference.

${ }^{5}$ Total digestible $(\mathrm{td})$ nutrients $(\%)=$ tdNFC + tdCP $+($ tdEE $\times 2.25)+$ tdNDF .

${ }^{6} \mathrm{NE}_{\mathrm{Lp}}(\mathrm{Mcal} / \mathrm{kg})=\mathrm{NE}_{\mathrm{L}}$ at production levels, as described by $\mathrm{NRC}(2001)$. 
Table 9. Effects of feeding monensin and different corn hybrids and interactions between these factors on daily excretion of urinary creatinine, allantoin, uric acid, and estimated rumen microbial CP production

\begin{tabular}{|c|c|c|c|c|c|c|c|c|}
\hline \multirow[b]{2}{*}{ Item } & \multicolumn{4}{|c|}{ Treatment $^{1}$} & \multirow[b]{2}{*}{$\mathrm{SEM}^{2}$} & \multicolumn{3}{|c|}{ Contrast $^{3}$ ( $P$-value $)$} \\
\hline & C-bm 3 & C-DP & M-bm3 & M-DP & & Monensin & Hybrid & I \\
\hline Creatinine, $\mathrm{m} M$ & 7.58 & 6.96 & 7.60 & 7.16 & 0.48 & 0.81 & 0.27 & 0.58 \\
\hline Allantoin, $\mathrm{m} M$ & 10.2 & 9.95 & 10.2 & 10.3 & 0.67 & 0.80 & 0.95 & 0.72 \\
\hline Uric acid, $\mathrm{m} M$ & 1.93 & 1.90 & 1.79 & 1.95 & 0.15 & 0.75 & 0.67 & 0.54 \\
\hline Hypoxanthine, $\mathrm{m} M$ & 1.01 & 1.09 & 0.93 & 1.02 & 0.14 & 0.55 & 0.53 & 0.97 \\
\hline $\mathrm{PD},{ }^{4} \mathrm{~m} M$ & 12.1 & 11.9 & 11.9 & 12.3 & 0.78 & 0.88 & 0.98 & 0.67 \\
\hline PP:creatinine & 1.66 & 1.75 & 1.61 & 1.71 & 0.07 & 0.54 & 0.18 & 0.97 \\
\hline Allantoin:creatinine & 1.39 & 1.47 & 1.38 & 1.44 & 0.06 & 0.68 & 0.27 & 0.91 \\
\hline Creatinine production, ${ }^{5} \mathrm{mmol} / \mathrm{d}$ & 243.2 & 250.2 & 239.2 & 250.6 & 10.92 & 0.87 & 0.40 & 0.83 \\
\hline $\mathrm{PD}$ production, ${ }^{6} \mathrm{mmol} / \mathrm{d}$ & 289.2 & 299.0 & 281.1 & 297.6 & 12.05 & 0.69 & 0.27 & 0.78 \\
\hline Allantoin production ${ }^{7} \mathrm{mmol} / \mathrm{d}$ & 243.2 & 250.2 & 239.2 & 250.6 & 10.70 & 0.87 & 0.40 & 0.83 \\
\hline Microbial $\mathrm{CP},{ }^{8} \mathrm{~g} / \mathrm{d}$ & 1,125 & 1,178 & 1,090 & 1,168 & 56.1 & -9 & -9 & -9 \\
\hline
\end{tabular}

${ }^{1} \mathrm{C}-\mathrm{bm} 3$ = no monensin, bm3 hybrid; C-DP = no monensin, dual-purpose control hybrid; M-bm3 = $300 \mathrm{mg} /$ $\mathrm{d}$ monensin, $b m 3$ hybrid; M-DP = $300 \mathrm{mg} / \mathrm{d}$ monensin, control dual-purpose hybrid.

${ }^{2}$ Highest standard error of treatment means is shown.

${ }^{3}$ Contrast for effects of feeding monensin and corn silage hybrid and monensin by hybrid interaction (I).

${ }^{4} \mathrm{PD}=$ total purine derivatives (allantoin + uric acid).

${ }^{5}$ Creatinine production $=(28 \times \mathrm{BW}) / 113.1$.

${ }^{6} \mathrm{PD}$ production $=[$ creatinine production $\times(\mathrm{PD}:$ creatinine $)]$.

${ }^{7}$ Allantoin production $=$ [creatinine production $\times($ allantoin:creatinine $\left.)\right]$.

${ }^{8}$ Microbial CP as estimated by Chen and Gomes (1992).

${ }^{9}$ Statistical test of diet on microbial CP production not conducted because values were estimated concentration of PD.

in total tract NDF digestibility were not observed, averaging $40.5 \pm 2.42 \%$ across treatments. This observation is in contrast to studies that observed an increase in apparent total tract digestibility of NDF. However, it is important to note that in these cases DMI was similar to that of the control hybrid (Greenfield et al., 2001). Although the proportion of potentially digestible NDF was greater for $b m 3$ corn silage, the lack of response in total tract NDF digestibility has been observed by others (Rook et al., 1977; Oba and Allen, 2000b) and is believed to occur when intake is increased (Oba and Allen, 2000c). In addition, increased total tract digestibility of animals consuming DP corn silage may have been due to greater rumen microbial activity and digestion (Russell and Wilson, 1996), which may have been supported by the higher rumen $\mathrm{pH}$.

\section{$P D$ and Creatinine Excretion}

We evaluated the concentration of urinary PD because they are commonly used as an indirect, noninvasive method to test for treatment differences in MCP. Table 9 lists the effects of experimental diets on urinary creatinine and PD. Table 9 also lists the ratio of PD to creatinine, allantoin to creatinine, and estimated MCP production as estimated by PD production (Chen and Gomes, 1992). Because MCP is only estimated based on concentrations of PD, diet effects were not compared statistically. We originally speculated that diets con- taining a greater proportion of fermentable fiber, as was the case in diets containing $b m 3$ corn silage, would result in an increase in total mass of ruminal MCP as indicated by PD production. Contrary to our hypothesis, PD production was not affected by diet and averaged $291.7 \pm 12.05 \mathrm{mmol} / \mathrm{d}$. Oba and Allen (2000c) observed that feeding diets containing $b m 3$ corn silage increased microbial $\mathrm{N}$ flow to the duodenum as well as microbial efficiency, possibly due to a faster rate of passage. Diets in that experiment were similar to those of the current experiment in that treatment diets contained more corn silage and less ground corn, but similar amounts of NDF and starch. Although the lack of response in MCP flow is surprising, in practical terms it is useful to know that rumen microbial protein yield may be maintained when feeding more bm 3 corn silage and less ground corn.

\section{N Metabolism}

In the current study, monensin did not affect $\mathrm{N}$ intake, fecal and urinary excretion, or milk $\mathrm{N}$ secretion, nor did it affect estimates of retained $\mathrm{N}$ (Table 10). This is in contrast to Spears (1990) who noted that the addition of monensin increased $\mathrm{N}$ digestibility in ruminants by between 2.6 and $3.8 \%$. This effect has been attributed to a reduction in ruminal degradation of preformed protein and a reduction in MCP flowing to the lower gut (Tedeschi et al., 2003). Given that the 
Table 10. Effects of feeding monensin and different corn hybrids and interactions between these factors on $\mathrm{N}$ metabolism

\begin{tabular}{|c|c|c|c|c|c|c|c|c|}
\hline \multirow[b]{2}{*}{ Item } & \multicolumn{4}{|c|}{ Treatment $^{1}$} & \multirow[b]{2}{*}{$\mathrm{SEM}^{2}$} & \multicolumn{3}{|c|}{ Contrast $^{3}(P$-value $)$} \\
\hline & C-bm3 & C-DP & M-bm3 & M-DP & & Monensin & Hybrid & I \\
\hline \multicolumn{9}{|l|}{ Mass, g/d } \\
\hline $\mathrm{N}$ intake & 634.3 & 584.4 & 626.5 & 591.4 & 2.22 & 0.99 & 0.06 & 0.74 \\
\hline Fecal N & 240.9 & 205.1 & 240.0 & 203.0 & 10.3 & 0.89 & $<0.01$ & 0.93 \\
\hline Digested N & 393.4 & 379.3 & 386.2 & 388.4 & 16.2 & 0.95 & 0.71 & 0.61 \\
\hline Urinary N & 200.4 & 218.6 & 218.5 & 206.9 & 14.9 & 0.82 & 0.82 & 0.31 \\
\hline Manure N & 439.4 & 421.8 & 456.9 & 407.9 & 21.7 & 0.93 & 0.12 & 0.46 \\
\hline Milk $\mathrm{N}^{4}$ & 189.5 & 175.0 & 180.0 & 179.9 & 9.11 & 0.80 & 0.41 & 0.42 \\
\hline $\mathrm{N}$ retained & 3.46 & -14.3 & -12.4 & 1.61 & 21.1 & 0.99 & 0.93 & 0.44 \\
\hline Productive $\mathrm{N}^{5}$ & 193.2 & 160.8 & 167.9 & 181.7 & 19.5 & 0.91 & 0.63 & 0.22 \\
\hline Milk N/Feed N & 32.4 & 32.5 & 31.3 & 33.5 & 1.44 & 0.97 & 0.41 & 0.47 \\
\hline \multicolumn{9}{|l|}{$\% \mathrm{~N}$ intake } \\
\hline Fecal N & 38.1 & 35.1 & 38.2 & 33.7 & 1.15 & 0.55 & $<0.01$ & 0.51 \\
\hline Urinary N & 31.8 & 38.6 & 36.3 & 36.5 & 2.31 & 0.59 & 0.12 & 0.14 \\
\hline Manure N & 69.8 & 73.5 & 74.4 & 70.0 & 2.85 & 0.84 & 0.92 & 0.14 \\
\hline Milk N & 29.7 & 30.1 & 28.7 & 31.0 & 1.21 & 0.93 & 0.26 & 0.43 \\
\hline $\mathrm{N}$ retained & 0.53 & -3.65 & -3.04 & -0.95 & 3.42 & 0.90 & 0.75 & 0.35 \\
\hline Productive N & 30.2 & 26.5 & 25.6 & 30.0 & 2.85 & 0.85 & 0.92 & 0.15 \\
\hline
\end{tabular}

${ }^{1} \mathrm{C}-\mathrm{bm} 3$ = no monensin, bm3 hybrid; C-DP = no monensin, dual-purpose control hybrid; M-bm3 = $300 \mathrm{mg} /$ $\mathrm{d}$ monensin, $b m 3$ hybrid; M-DP = $300 \mathrm{mg} / \mathrm{d}$ monensin, control dual-purpose hybrid.

${ }^{2}$ Highest standard error of treatment means is shown.

${ }^{3}$ Contrast for effects of feeding monensin and corn silage hybrid and monensin by hybrid interaction (I).

${ }^{4}$ Milk $\mathrm{N}$ yield $(\mathrm{kg})$ per $\mathrm{kg}$ of $\mathrm{N}$ intake $\times 100$.

${ }^{5}$ Productive $\mathrm{N}=$ milk $\mathrm{N}+$ retained $\mathrm{N}$.

concentration of rumen ammonia and urinary excretion of PD was unaffected, we speculate that $\mathrm{N}$ utilization was not affected because monensin did not affect ruminal protein degradation.

Weiss and Wyatt (2006) evaluated the effects of $b m 3$ corn silage and MP supply on $\mathrm{N}$ excretion. Results of that experiment suggested that cows fed $b m 3$ corn silage excreted less $\mathrm{N}$ via manure and secreted more milk $\mathrm{N}$. This observation differs from the current experiment (Table 10) because cows consuming diets containing bm3 corn silage were observed to excrete more fecal $\mathrm{N}$ ( 240.5 vs. $204.1 \pm 10.3 \mathrm{~g} / \mathrm{d}$ ) but secrete similar amounts of urinary and milk N, averaging $211.1 \pm 14.9$ and 181.1 $\pm 9.11 \mathrm{~g} / \mathrm{d}$ respectively, across treatments. We assume that the increase in fecal $\mathrm{N}$ excretion of $b m 3$ treatments was in response to increasing intake and decreasing $\mathrm{N}$ digestibility. However, it should also be noted that the decrease in apparent $\mathrm{N}$ digestibility may have been a function of increasing intake that may have increased in metabolic fecal N. Because of the effect of $\mathrm{N}$ intake, diet comparisons of fecal, urine, and manure $\mathrm{N}$ excretion were also based on output per unit of $\mathrm{N}$ consumed (Table 10). Similar to the total mass excreted, the proportion of $\mathrm{N}$ excreted in the feces was greater for cows consuming diets containing bm3 corn silage (38.1 vs. $34.4 \pm 1.15$ ). However, no significant differences were observed in total manure $\mathrm{N}$, which averaged $71.9 \pm$ $2.85 \%$ across treatments. These observations are consistent with other reports that noted a reduction in urinary $\mathrm{N}$ excretion when feeding $b m 3$ corn silage (Greenfield et al., 2001; Tine et al., 2001). Across treatments, fecal $\mathrm{N}$ accounted for $36.3 \pm 1.15 \%$ of the total $\mathrm{N}$ consumed. A similar proportion of $\mathrm{N}$ consumed was excreted in the urine $(35.8 \pm 2.31 \%)$. These observations are in support of the suggestion that $\mathrm{N}$ is excreted equally in the feces and urine; however, $\mathrm{N}$ consumed in excess is believed to be excreted in the urine (Kebreab et al., 2001). We evaluated the relationship between $\mathrm{N}$ intake and $\mathrm{N}$ output in milk, feces, and urine (Figures 1,2 , and 3). As expected, there were positive linear relationships between $\mathrm{N}$ intake and milk $\mathrm{N}$ (Figure 1) and fecal $N$ (Figure 2) output $\left(\mathrm{R}^{2}=0.32\right.$ and 0.50 respectively). In contrast to the observations of Kebreab et al. (2001), the relationship between $\mathrm{N}$ intake and urinary nitrogen excretion (Figure 3 ) was poor $\left(\mathrm{R}^{2}=\right.$ 0.02 ). The lack of relationship in the current study may be explained, in part, by a lack of precision in the method used to estimate total urinary volume. Our study differed from that of Kebreab et al. (2001) who used total urine collection. An additional factor may be that, on average, animals were in low or negative balance of $\mathrm{N}$ (Table 8). Although calculated energy balance was negative this was not reflected in BCS, which was observed to be similar $(P=0.52)$, averaging $3.03 \pm 0.07$. Given the short duration of the study and associated lack of precision in BCS estimates it may be possible that some animals were in negative energy balance and were using gluconeogenic amino acids for energy. 


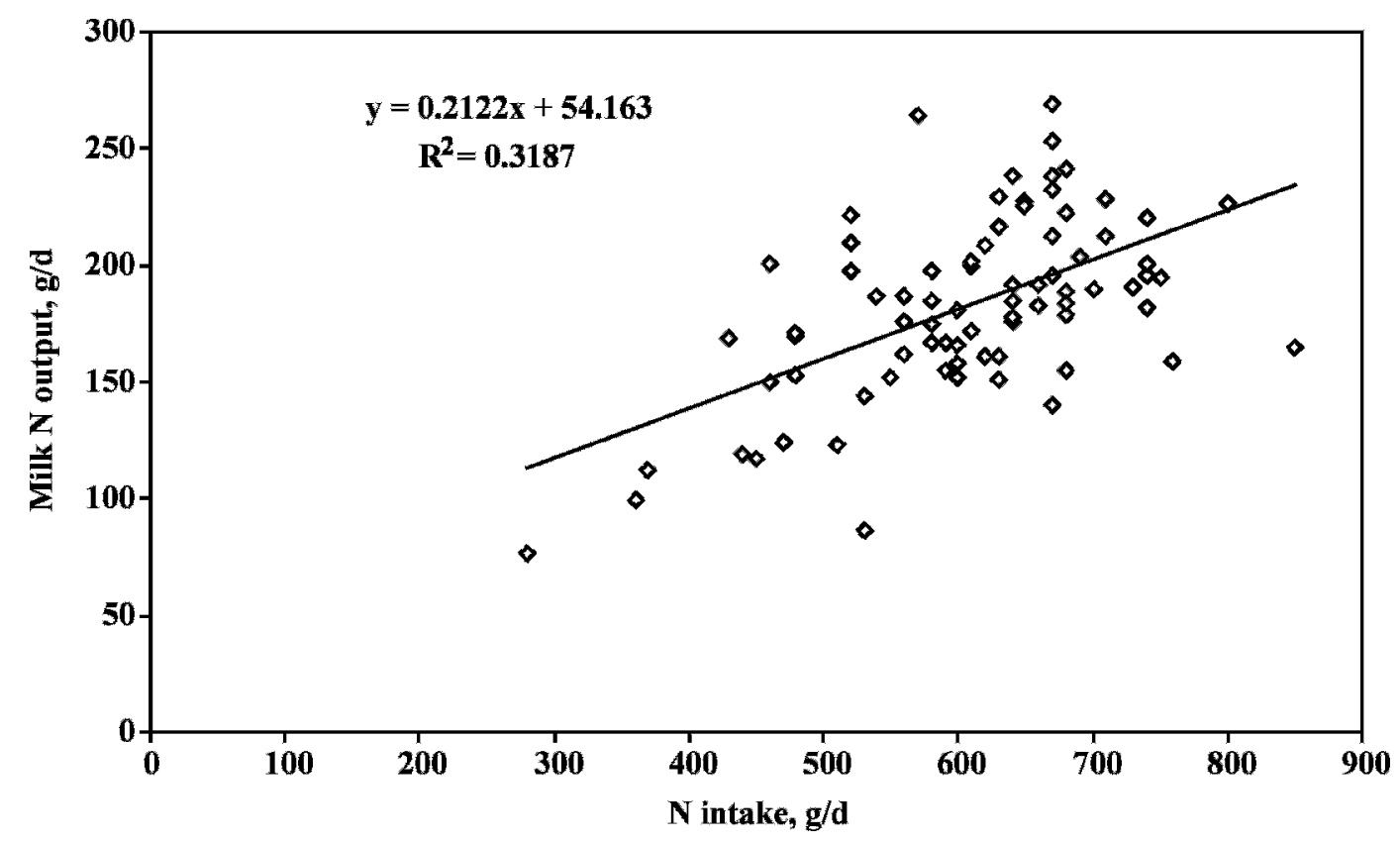

Figure 1. Relationship between total $\mathrm{N}$ intake and milk $\mathrm{N}$ output with linear equation for fitted line denoted.

Consequently, catabolism of body protein would result in an increase of urine N (Firkins and Reynolds, 2005). This may further explain why a reduction in urinary $\mathrm{N}$ is observed when feeding bm3 corn silage (Greenfield et al., 2001; Tine et al., 2001). Practically, this is useful to understand, because reducing the amount of $\mathrm{N}$ ex- creted in the urine, rather than the feces, is an effective way of reducing ammonia volatilization and pollution.

\section{Milk Production and Composition}

No treatment effects were observed to affect milk production, which averaged $37.7 \pm 2.11 \mathrm{~kg}$ across treat-

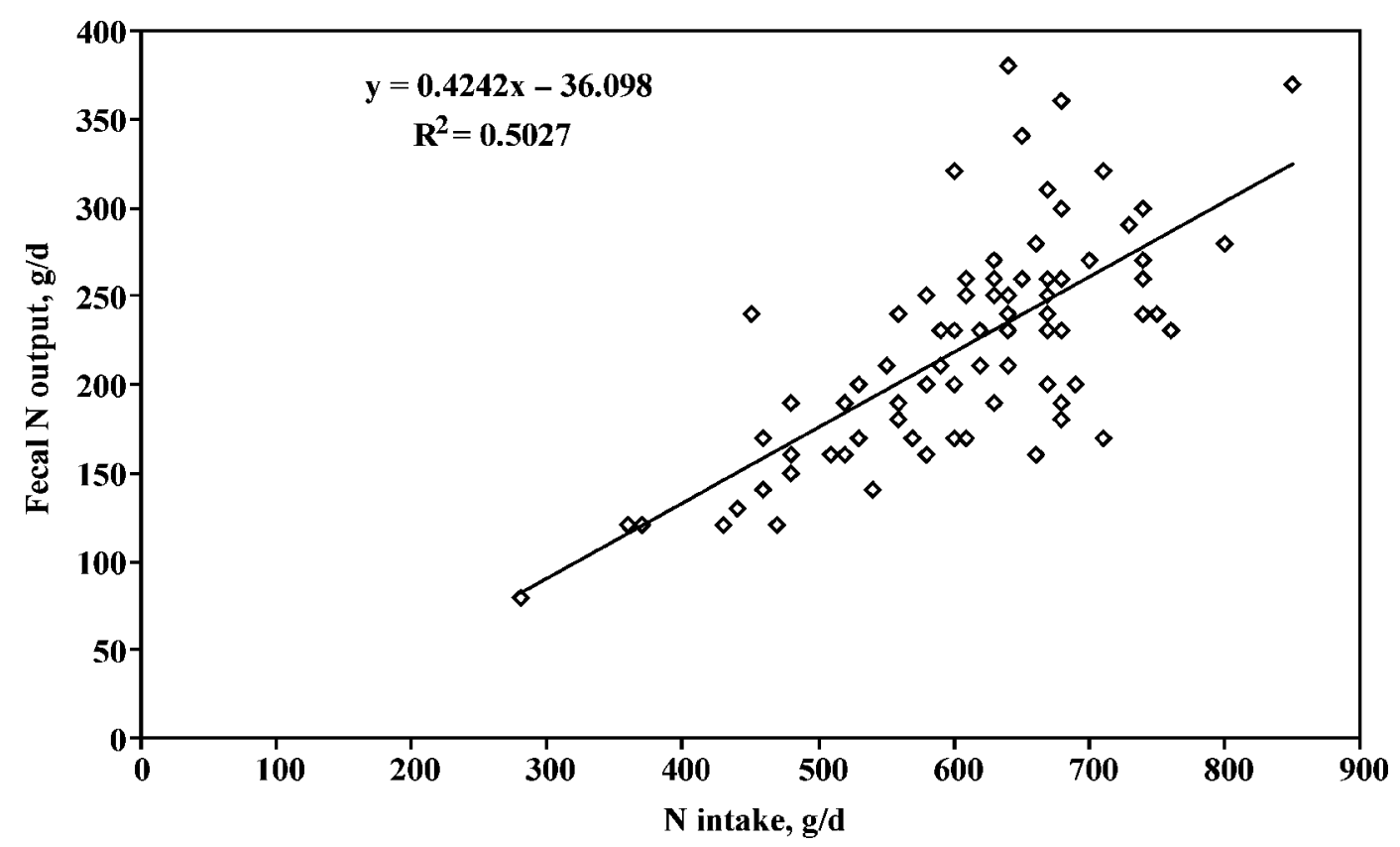

Figure 2. Relationship between total $\mathrm{N}$ intake and fecal $\mathrm{N}$ output with linear equation for fitted line denoted. 


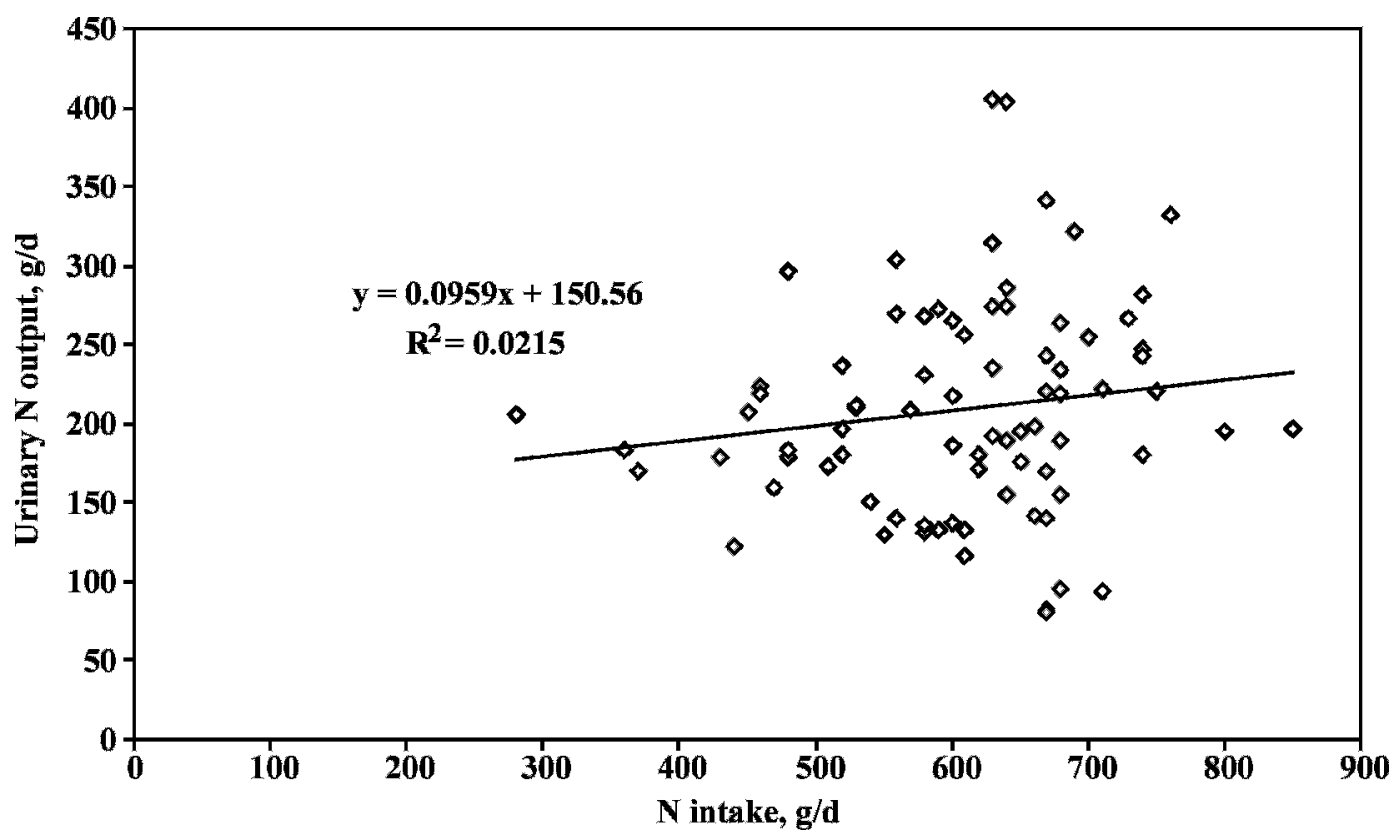

Figure 3. Relationship between total $\mathrm{N}$ intake and urinary $\mathrm{N}$ output with linear equation for fitted line denoted.

ments (Table 6). Similarly, fat and protein percentage and yield were not observed to be different. The percentage of milk fat and protein averaged $3.60 \pm 0.16 \%$ and $3.04 \pm 0.06 \%$, and yield of these components averaged $1.34 \pm 0.08$ and $1.13 \pm 0.06 \mathrm{~kg} / \mathrm{d}$. The lack of effect of monensin is in contrast to those reported in a review of published studies (McGuffey et al., 2001). Specifically, in 11 published studies, cows fed monensin produced an average of $1.3 \mathrm{~kg} / \mathrm{d}$ more milk and $26 \mathrm{~g} / \mathrm{d}$ more milk protein than those not fed monensin. These effects are generally attributed to an increase in rumen propionate production and the rate of gluconeogenesis (Arieli et al., 2001) and an increase in glucose supply to support milk and milk protein production (Beckett et al., 1998; Ipharraguerre and Clark, 2003). Although we are unable to put forth any reasonable explanation for the lack of responses observed in the current study when feeding monensin, results may indicate that because ruminal propionate was not affected, energy status was not improved with the inclusion of monensin.

With respect to corn silage hybrid, production results are in contrast to most studies in which milk production is greater for cows consuming bm3 corn silage (Oba and Allen, 1999, 2000a; Tine et al., 2001; Ebling and Kung, 2004; Weiss and Wyatt, 2006). However, increased production has not been observed in all studies (Greenfield et al., 2001; Qiu et al., 2003). In the current experiment, the standard error of the mean associated with milk yield was greater than expected. Given these results some caution should be used in interpreting results of the statistical tests regarding effects on milk yield. The high degree of variation in the data set may also contribute to commitment of a type II error; concluding that dietary treatment or interaction has no effect when, in reality, it does (Kononoff and Hanford, 2006). Nonetheless, a primary goal of the current study was to evaluate whether milk production could be improved by increasing MCP by balancing diets to contain greater amounts of ruminally fermentable fiber. Although we did not directly measure duodenal flow of protein, indirect estimates of MCP using urinary PD were not affected and did not support a greater level of production.

\section{CONCLUSIONS}

The inclusion of the ionophore monensin in corn silage-based diets increased rumen $\mathrm{pH}$ but did not significantly affect DMI, apparent digestibility, or proportion of ruminal acetate or propionate, nor did it affect milk production or $\mathrm{N}$ utilization. Diets formulated to contain $54.3 \%$ bm3 corn silage resulted in greater DMI but similar milk production. Indirect estimation of rumen MCP production using urinary PD was not different when $b m 3$ corn silage was fed. The increase in DMI negatively affected apparent digestibility of $\mathrm{N}$ but not $\mathrm{NDF}$. This resulted in a greater amount of $\mathrm{N}$ to be excreted in the feces even though total manure N excretion was not affected. No interaction between monensin and corn silage hybrid was observed for any of these variables. 


\section{ACKNOWLEDGMENTS}

This research was a component of a USDA NC Regional Project NC-1119. The authors thank the personnel at the University of Nebraska Dairy Research Unit (Mead, NE) for care of the experimental animals during the experiment. The assistance of A. George, J. Warner, Z. Alger, and D. Hudson for sample collection and analysis is much appreciated. The technical assistance of J. Benton and editorial suggestions of J. Kelzer are also appreciated.

\section{REFERENCES}

Ali Haimoud, D., M. Vernay, C. Bayourthe, and R. Moncoulon. 1995. Avoparcin and monensin effects on the digestion of nutrients in dairy cows fed a mixed diet. Can. J. Anim. Sci. 75:379-385.

Allison, M. J. 1970. Nitrogen metabolism of ruminal micro-organisms. Pages 456-473 in Physiology of Digestion and Metabolism in the Ruminant. A. T. Phillipson, ed. Oriel Press, Newcastle upon Tyne, UK.

AOAC. 2000. Official Methods of Analysis. Vol. 1 and 2. 17th ed. AOAC International, Gaithersburg, MD.

Arieli, A., J. E. Vallimont, Y. Aharoni, and G. A. Varga. 2001. Monensin and growth hormone effects on glucose metabolism in the prepartum cow. J. Dairy Sci. 84:2770-2776.

Beckett, S., I. Lean, R. Dyson, W. Tranter, and L. Wade. 1998. Effects of monensin on the reproduction, health, and milk production of dairy cows. J. Dairy Sci. 81:1563-1573.

Chen, G., and J. B. Russell. 1989. More monensin-sensitive, ammonia-producing bacteria from the rumen. Appl. Environ. Microbiol. 55:1052-1057.

Chen, X. B. 1997. Neway Excel: A utility for processing data of feed degradability and in-vitro gas production (version 6.0). Rowett Research Institute. UK.

Chen, X. B., and M. J. Gomes. 1992. Estimation of microbial protein supply to sheep and cattle based on urinary excretion of purine derivatives-An overview of the technical details. Rowett Research Institute, Bucksburn, Aberdeen, UK.

Ebling, T. L., and L. Kung. 2004. A comparison of processed conventional corn silage to unprocessed and processed brown midrib corn silage on intake, digestion, and milk production by dairy cows. J. Dairy Sci. 87:2519-2526.

Firkins, J. L., and C. K. Reynolds. 2005. Whole animal nitrogen balance in cattle. Pages 167-185 in Nitrogen and Phosphorus Nutrition of Cattle and Environment. A. N. Hristov and E. Pfeffer, ed. CAB International, Wallingford, UK.

Gonda, H. L. 1995. Nutritional status of ruminants determined from excretion and concentration of metabolites in body fluids. PhD Diss. Swedish Univ. of Agricultural Sciences, Dept. Anim. Nutr. Management, Uppsala.

Green, B. L., B. W. McBride, W. D. Sandals, K. E. Leslie, R. Bagg, and P. Dick. 1999. The impact of the monensin controlled release capsule upon subclinical acidosis in the transition dairy cow. J. Dairy Sci. 82:333-342.

Greenfield, T. L., R. L. Baldwin, R. A. Erdman, and K. R. McLeod. 2001. Ruminal fermentation and intestinal flow of nutrients by lactating cows consuming brown midrib corn silages. J. Dairy Sci. 84:2469-2477.

Heinrichs, A. J., and P. J. Kononoff. 2002. Evaluating particle size of forages and TMRs using the Penn State Particle Size Separator. DAS 96-20. Technical Bulletin of The Pennsylvania State University, College of Agriculture Science, Cooperative Extension.

Huhtanen, P., K. Kaustell, and S. Jaakkola. 1994. The use of internal markers to predict total digestibility and duodenal flow of nutrients in cattle given six different diets. Anim. Feed Sci. Technol. 48:211-227.
Ipharraguerre, I. R., and J. H. Clark. 2003. Usefulness of ionophores for lactating dairy cows: A review. Anim. Feed Sci. Technol. 106:39-57.

Jones, S. J., D. L. Starkey, C. R. Calkins, and J. D. Crouse. 1990. Myofibrillar protein turnover in feed-restricted and realimented beef cattle. J. Anim. Sci. 68:2707-2715.

Kebreab, E., J. France, D. E. Beever, and A. R. Castillo. 2001. Nitrogen pollution by dairy cows and its mitigation by dietary manipulation. Nutr. Cycl. Agroecosyst. 60:275-285.

Kononoff, P. J., and K. Hanford. 2006. Estimating statistical power of mixed models used in dairy nutrition experiments. J. Dairy Sci. 89:3968-3971.

Kononoff, P. J., A. J. Heinrichs, and D. A. Buckmaster. 2003a. Modification of the Penn State forage and TMR separator and the effects of moisture content on its measurements. J. Dairy Sci. 86:1858-1863.

Kononoff, P. J., H. A. Lehman, and A. J. Heinrichs. 2003b. The effect of corn silage particle size on eating behavior and rumination in lactating dairy cattle. J. Dairy Sci. 86:3343-3353.

Leonardi, C., F. Giannico, and L. E. Armentano. 2005. Effect of water addition on selective consumption (sorting) of dry diets by dairy cattle. J. Dairy Sci. 88:1043-1049.

Leonardi, C., M. Stevenson, and L. E. Armentano. 2003. Effect of two levels of crude protein and methionine supplementation on performance of dairy cows. J. Dairy Sci. 86:4033-4042.

Lykos, T., G. A. Varga, and D. Casper. 1997. Varying degradation rates of total nonstructural carbohydrates: Effects on ruminal fermentation, blood metabolites, and milk production and composition in high producing Holstein cows. J. Dairy Sci. 80:33413355.

Marita, J. M., W. Vermerris, J. Ralph, and R. D. Hatfield. 2003. Variations in the cell wall composition of maize brown midrib mutants. J. Agric. Food Chem. 51:1313-1321.

McCarthy, F. D., W. G. Bergen, and D. R. Hawkins. 1983. Muscle protein turnover in cattle of differing genetic backgrounds as measured by urinary Nr-methylhistidine excretion. J. Nutr. 113:2455-2463.

McGuffey, R. K., L. F. Richardson, and J. I. D. Wilkinson. 2001. Ionophore for dairy cattle: Current status and future outlook. J. Dairy Sci. 84(E Suppl.):E194-E203.

NRC. 2001. Nutrient Requirements of Dairy Cattle. 7th rev. ed. Natl. Acad. Sci., Washington, DC.

Oba, M., and M. S. Allen. 1999. Effects of brown midrib 3 mutation in corn silage on dry matter intake and productivity of high yielding dairy cows. J. Dairy Sci. 82:135-142.

Oba, M., and M. S. Allen. 2000a. Effects of brown midrib 3 mutation in corn silage on productivity of dairy cows fed two concentrations of dietary neutral detergent fiber: 1 . Feeding behavior and nutrient utilization. J. Dairy Sci. 83:1333-1341.

Oba, M., and M. S. Allen. 2000b. Effects of brown midrib 3 mutation in corn silage on productivity of dairy cows fed two concentrations of dietary neutral detergent fiber: 2 Chewing activities. J. Dairy Sci. 83:1342-1349.

Oba, M., and M. S. Allen. 2000c. Effects of brown midrib 3 mutation in corn silage on productivity of dairy cows fed two concentrations of dietary neutral detergent fiber: 3 . Digestibility and microbial efficiency. J. Dairy Sci. 83:1350-1358.

Osborne, J. K., T. Mutsvangwa, O. Alzahal, T. F. Duffield, R. Bagg, P. Dick, G. Vessie, and B. W. McBride. 2004. Effects of monensin on ruminal forage degradability and total tract diet digestibility in lactating dairy cows during grain-induced subacute ruminal acidosis. J. Dairy Sci. 87:1840-1847.

Plaizier, J. C., A. Martin, T. Duffield, R. Bagg, P. Dick, and B. W. McBride. 2000. Effect of a prepartum administration of monensin in a controlled release capsule on apparent digestibilities and nitrogen utilization in transition dairy cows. J. Dairy Sci. 83:2918-2925.

Qiu, X., M. L. Eastridge, and Z. Wang. 2003. Effects of corn silage hybrid and dietary concentration of forage NDF on digestibility and performance by dairy cows. J. Dairy Sci. 86:3667-3674. 
Rook, J. A., L. D. Muller, and D. B. Shank. 1977. Intake and digestibility of brown-midrib corn silage by lactating dairy cows. J. Dairy Sci. 60:1894-1904.

Ruiz, R., G. L. Albrecht, L. O. Tedeschi, G. Jarvis, J. B. Russell, and D. G. Fox. 2001. Effect of monensin on the performance and nitrogen utilization of lactating dairy cows consuming fresh forage. J. Dairy Sci. 84:1717-1727.

Russell, J. B., J. D. O’Connor, D. G. Fox, P. J. Van Soest, and C. J. Sniffen. 1992. A net-carbohydrate and protein system for evaluating cattle diets: I Ruminal fermentation. J. Anim. Sci. 70:3551-3561.

Russell, J. B., and H. J. Strobel. 1989. Minireview: Effect of ionophores on ruminal fermentation. Appl. Environ. Micro. 55:1-6.

Russell, J. B., and D. B. Wilson. 1996. Why are ruminal cellulolytic bacteria unable to digest cellulose at low pH? J. Dairy Sci. 79:1503-1509.

SAS Institute. 1999. SAS/STAT User's Guide. Version 8. SAS Institute Inc., Cary, NC.

Shingfield, K. J., and N. W. Offer. 1998. Evaluation of milk allantoin excretion as an index of microbial protein supply in lactating dairy cows. Anim. Sci. 67:371-385.

Spears, J. W. 1990. Ionophores and nutrient digestion and absorption in ruminants. J. Nutr. 120:632-638.

Tedeschi, L. Q., D. G. Fox, and T. P. Tylutki. 2003. Potential environmental benefits of ionophores in ruminant diets. J. Environ. Qual. 32:1591-1602.

Tilley, J. M. A., and R. A. Terry. 1963. A two stage technique for in vitro digestion of forage crops. J. Brit. Grassl. Soc. 18:104-111.

Tine, M. A., K. R. McLeod, R. A. Erdman, and R. L. Baldwin. 2001. Effects of brown midrib corn silage on the energy balance of dairy cattle. J. Dairy Sci. 84:885-895.

Valadares, R. F. D., G. A. Broderick, S. C. Valadares Filho, and M. K. Clayton. 1999. Effect of replacing alfalfa silage with high moisture corn on ruminal protein synthesis estimated from excretion of total purine derivatives. J. Dairy Sci. 82:2686-2696.
Van Soest, P. J. 1994. Nutritional Ecology of the Ruminant. 2nd ed. Comstock Publishing Associated, a division of Cornell University Press., Ithaca, NY.

Varga, G. A., and E. Kolver. 1997. Microbial and animal limitations to fiber digestion and utilization. J. Nutr. 127:819S-823S.

Vignols, F., J. Rigau, M. A. Torres, M. Capellades, and P. Puigdomenech. 1995. The brown midrib3 (bm3) mutation in maize occurs in the gene encoding caffeic acid O-methyl transferase. Plant Cell 7:407-416.

Weiss, W. P. 1994. Estimation of digestibility of forages by laboratory methods. Pages 644-681 in Forage Quality, Evaluation, and Utilization. G. C. Fahey Jr., ed. Am. Soc. Agron., Crop Sci. Soc. Am. Soil Sci. Soc. Am., Madison WI.

Weiss, W. P., H. R. Conrad, and N. R. St. Pierre. 1992. A theoretically based model for predicting total digestible nutrient values of forages and concentrates. Anim. Feed Sci. Technol. 39:95-110.

Weiss, W. P., and D. J. Wyatt. 2006. Effect of corn silage hybrid and metabolizable protein supply on nitrogen metabolism of lactating dairy cows. J. Dairy Sci. 89:1644-1653.

Whittet, K. M. 2004. Factors affecting variability in urinary creatinine and purine derivative excretion in beef cattle. MS Diss., Univ. Nebraska-Lincoln, Lincoln.

Wildman, E. E., G. M. Jones, P. E. Wagner, H. F. Troutt, and T. N. Lesch. 1982. A dairy cow body condition scoring system and its relationship to selected production characteristics. J. Dairy Sci. 65:495-501.

Yang, C., and M. J. Yang. 2002. Response of forage fiber degradation by ruminal microorganisms to branched chain volatile fatty acids, amino acids and dipeptides. J. Dairy Sci. 85:1183-1190.

Yang, C. M. J., and G. A. Varga. 1989. Effect of three concentrate feeding frequencies on rumen protozoa, rumen digesta kinetics, and milk yield in dairy cows. J. Dairy Sci. 72:950-957.

Yokoyama, M. T., and K. A. Johnson. 1988. Microbiology of the rumen and intestine. Pages 125-144 in The Ruminant Animal: Digestive Physiology and Nutrition. D. C. Church, ed. Prentice-Hall, Englewood Cliffs, NJ. 